\title{
What determines the allowance of bank loans for investment - an overview of Kosovo SMEs
}

\author{
Florin Peci, Faculty of Business Administration, University of Peja, \\ The Republic of Kosovo
}

\begin{abstract}
The present study determines firm and entrepreneurship characteristics of small and medium enterprises (SMEs) active in international trade towards investment and growth. Using data collected through self-administered interviews with 180 SMEs in Kosovo, we investigated factors that influence the investment growth financed by bank loans. Econometric model of linear regression indicates that a large number of firm and entrepreneur characteristics including experience, sector, business plan, audit statements, collateral significantly affect investment growth. Our findings suggest that especially education of SMEs managers have higher rate of financing sources through bank loan. The study concludes with respective findings translated into recommendations, which have to be considered by relevant stakeholders active in entrepreneurship and policymaking.
\end{abstract}

Key words: Bank loans, investments, SMEs, international trade, Kosovo

\section{INTRODUCTION}

It is widely acknowledged that SMEs are the engine of economic growth (Acs and Audretsch, 1990; Johnson and Loweman, 1995). SMEs contribute to gross domestic product (GDP), generate employment and enhance technologic innovation (Acs and Audretsch, 1990). High relevance of SMEs and crucial role for the post conflict countries to overpass difficulties in their transformation period has been also widely confirmed (Aidis and Estrin, 2006 Audretsch and Klepper, 2000; McMillan and Woodruff, 2002, Hoxha, 2008).

The empiric studies of SME financing is of particular importance (Schiffer and Weder, 2001; Beck et al, 2005; Krasniqi, 2007). Access to finance, mainly bank financing remains the most crucial element in the development of SMEs sector (World Bank, 2005). Access to financing is becoming the biggest obstacle particularly in transition countries SMEs and in a long-run it is affecting the growth of SME sector. In comparison to big companies, small companies are always being in disadvantage concerning financing (Schiffer and Weder, 2001; Beck et al, 2005).

Explain SMEs financing from the perceptive of supply side, Beck et al. (2007), with a survey of 91 banks in 45 countries found that banks consider SMEs as very profitable sector. The authors found little variances on how banks interact with SMEs in developed and developing economies. Conclusion of the research states that enabling environment is more important than the size of the firm or the bank (Beck et al, 2005).

A considerable number of scholars confirm that SMEs face many difficulties concerning finding loans due to requests for unnecessary documentations that results in higher transaction costs (Beck et al., 2006). According to Audretsch and Elston (2006), small firms confront higher financial difficulties than large ones (Beck et al, 2006; Oliveira and Fortunato, 2006). Due to the information asymmetry, SMEs use internal financial resources rather than external ones, i.e. bank loans to satisfy their investment needs 


\section{Florin Peci \\ What determines the allowance of bank loans for investment - an overview of Kosovo SMEs}

and growth (Brinckmann et al, 2011; Zhao et al, 2006; Deakins et al., 2008; EBRD, 1999; Pissardies et al., 2003; Klapper et al., 2002).

Kosovo, as one of the newest states in the world, is undergoing transitional period and it is not free from financial constraints for SMEs growth. The bank sector in Kosovo is relatively new. Currently, there are nine (9) newly established commercial banks and financial support in the form of investment loans are being done through these banks. Investment loans, in particular, are of higher relevance to those SMEs that operate in international trade aiming for development and expansion of their activities.

The objective of this study is to assess the role of the factors that influence the investment growth of those SMEs that operate in international trade. In order to study relevance of the main factors and their impact on investment growth through bank loans we have developed econometric model that defines key variables on investment growth of the SMEs active in international trade. The group of variables refers to firm characteristic, entrepreneurship and external sources of finance.

The structure of the work is as follows. The first section provides introduction and background to bank sector in Kosovo and internalization of Kosovo SMEs. In next section, we discuss the theoretical aspects through literature review. In section three, we provide the research hypotheses, outlay data and model specification. In section four, we discuss results. The paper concludes with findings and recommendations.

\section{BANKING SECTOR IN KOSOVO}

The banking sector in Kosovo is quite new. It was established after the conflict of 1999. The banking system in Kosovo is regulated the Central Bank of Kosovo (CBK). CBR issues license, at the same time monitors, and regulates the banking system. The banking sector is just one of the financial institutions in Kosovo financing system (CBK, 2012). Financial sector comprises in total 70 financial institutions, including banking industry, insurance companies, pension funds, and others (CBK, 2011). The development of banking sector in Kosovo is characterized with the presence of foreign capital because of the fact that there was not a local capital in place in the beginning of establishment of banking system. The first bank established with the mixture of foreign and local capital was Pro-Credit Bank and it still operates in Kosovo as one of the most successful banks. Its success lies on the collection of deposits and its efficient use as loans. Currently, around 72 percent of assets belongs to foreign banks. Seven from nine banks operating in Kosovo are of foreign capital. While the presence of foreign financial institutions has had positive impact on the modernization of the banking system in Kosovo, there is a risk of dependency on foreign capital.

Since the establishment of the banking sector in Kosovo it was evidenced the growth of deposits. It amounted to almost 2.1 billion Euros recording an annual growth of about 8.5 percent (CBK, 2011; MTI, 2013). Loans are dominant in overall activities of the commercial banks. Around sixty-seven percent of loans goes to SMEs and the remaining 30 percent goes to households. The loan structure is comprised of 71 percent in the service sector out of which 73 percent in trade sector. Industry sector market uses 25 percent of total bank loans (CBK, 2012). Agriculture sector holds lower share with only 3.5 percent of total bank loans (CBK, 2012).

One important issue to be mentioned here is the fact that interest rates have been remaining high in comparison to the interest rates in the region regardless of expanded loan volumes annually (CBK, 2012). Practically this means that SMEs are obtaining investment loans with unfavorable interest rates from banks. High interest rates in the banking sector in Kosovo is being justified by banks. They state that high rates are due to insecurity with loan payback. Banks claim several factors as country-level risk like weak institutions, corruption, non-functional justice sector, information asymmetry, low-quality business plans, insecure collateral implementation and many others (CBK, 2012). Despite the above statement, there is a general opinion of businesses in Kosovo that states commercial banks to be engaged in silent informal agreement for sticking to high interest rates for loan allowance. As a result, SME sector is using bank loans for business investments only when they do not have other alternatives. Businesses prefer usage of internal sources for investments. 


\section{INTERNATIONALIZATION OF KOSOVO SMES}

Young and dynamic economy of Kosovo is characterized by its transformation from centrally planned economy to free market economy with the end of the 1999conflict. Before that, Kosovo economy was typical agrarian with slow development industry in 1980s. The functionalization of the entrepreneurship in former Yugoslavia has been established under the Law on Enterprises in 1988 and it provided basic conditions for private businesses (Hoxha, 2009). In fact, SMEs in Kosovo were sensitive to political situation. Due to Serbian regime repression that Kosovo Albanians were fired from public enterprises. So, SMEs have been established as a way of survival where families and community generated income for themselves and assisted the others.

After 1999, SMEs started to be regulated by United Nations Mission in Kosovo (UNMIK's) legal framework. It was this time when SMEs started with international trade. At first, SMEs involvement in international trade was a result of high demand for imported goods as a result of socio-economic restructuring of the country and growing international integration. Public enterprises inherited from previous system underwent privatization process under Kosovo Trust Agency (KTA). At this stage, Kosovo engaged in Free Trade Agreement with neighboring countries i.e. FYROM, Republic of Albania, Republic of Montenegro, $\mathrm{BiH}$, etc. Later, this cooperation resulted in engagement in a general Free Trade Agreements with countries in region known as Central European Free Trade Agreement (CEFTA).After the declaration of Kosovo independence in 2008, UNMIK authorities for regulating international trade have been handed to local authorities.

In 2012, Kosovo reached an amount of 3 billion Euros in trade flows, an increase of 15 percent compared with a year ago. Exports, on the other hand, achieved around 312 million Euros that covers about 10 percent the total imports in Kosovo in 2012. Main trading partners of Kosovo are European Countries (EU) and CEFTA Countries. Kosovo exports to the EU countries were about 45 percent in 2011 of the total exports and there is an increase of 5 percent comparing to previous year (MTI, 2011). Export to CEFTA countries in 2012 increased by 26 percent compared to previous years. Kosovo imports to EU countries were 42 percent of the overall total imports in 2012 and there is an increase of 17 percent compared to previous year. Imports from CEFTA countries were 37 percent of total value.

In Kosovo exports and imports, SMEs are dominating. Currently, there are around 110000 registered SMEs (MTI, 2009), of which 28000 are engaged in international trade. In their daily business in international trade, SMEs face many problems such as lack of experience, lack of professionalism, limited business information, lack of institutional support, lack of financial means, and others. An evident obstacle is an access for existing bank loans. SMEs in international trade have positive approach towards bank loans for investment purposes. Banks hesitate to grant bank loans to SMEs due to high risk SMEs are exposed operating in international trade. In fact, there is higher-than-even need for financial support in the form of bank loan for those SMEs operating in international trade because of their intention to expand. Overall, there is a tension between a need of SMEs for financial support and bank loan schemes in Kosovo.

\section{THEORY AND LITERATURE REVIEW}

The theoretical framework to which most of the current research literature adheres has been quite helpful in understanding SME financing developed and developing countries through which SME succeeded positive performance in investments, growth and development, internationalization. The theoretical frameworks are many; trade off theory by Modigliani and Miller (1958), the pecking order theory (Myers and Majluf, 1984), managerial theory of investments (Marris, 1963), agency theory by Jensen and Meckling (1976) and extended version of agency theory by Stiglitz and Weiss (1981).

Based on the neoclassical theory of investment (M-M), internal and external sources of financing are more relevant than the capital structure for the value of the firm. In situations where there is a perfect functioning of the market, the choice between financing through own capital or debt is irrelevant. Therefore, the cost of capital and the market value of the firm are independent from the value of the firm (Modigliani and Miller, 1958). The theory of M-M starts at the following paradigms; there are no taxes, 
transaction costs, and bankruptcy costs, there is equal cost of debt for companies and for investors, symmetrical information in the market and there is no influence of debt in the profit of the company before interest and taxation.

Contrary to M-M, Scott (1972) firmly emphasized that $100 \%$ tax shield does not exist in reality because of distress costs. Scott states that debt leads to legal obligation to pay interest and principal. Later Fatoki and Asah conclude that if a firm cannot meet its debt obligation it is forced to declare bankrupt that incurs associated costs (Fatoki and Asah, 2011). This theory, in fact, does not take into the consideration all the other factors such as bankruptcy costs of the firm, agency costs, debt impact in profit, asymmetry of information. Therefore, this theory has been challenged by other theories (Harris and Raviv, 1991).

According to Pecking Order Theory (POT), the firm initially should use internal sources of financing rather than external ones and, regarding external sources, they prefer debt to capital (Donaldson, 1961). Thus, initially SMEs should use their accumulated profit, amortization, debt, and, finally, the equity capital. This theory states that firms finance their investment requirements following hierarchic order. This can lead to existence of the asymmetry of information between managers (insiders) and investors (outsiders). Consequently, managers have more information than investors (Myers and Majluf, 1984).

The Agency Theory of Stiglitz and Weiss (1981) describes the problem arising as a result of asymmetrical information between managers and shareholders on one hand, and the problem among shareholders, managers and creditors and others. They argue that only SMEs are aware of their real financial structure, the real strength of their investment projects, and the tendencies for settling up the debt. Therefore, the firm possesses superior private information (Mazanai and Fatoki, 2012).

\section{DATA, RESEARCH HYPOTHESIS, AND MODEL SPECIFICATION}

For the purpose of this study, data has been gathered through questionnaire survey undertaken in 2012 . Only SMEs that are involved in international trade make up the sample for this study. SMEs has been chosen randomly from the database at the Agency for Businesses Registration in the Ministry of Industry and Trade of Kosovo and it is stratified into three basic sectors in order to reflect differences among production, trade and service firms. Face to face interviews were conducted with owners and managers or financial managers of the firms. The questionnaire was designed to obtain information on firm characteristics, entrepreneurship and financing through bank loans.

Below-mentioning hypothesis has been developed for further study and check:

H1: Exporting SMEs are using more bank loans for investment growth than non-exporting SMEs

H2: SMEs with business plans are using more bank loans for investments than those that have not yet developed business plan

H3: SMEs possessing colateral show higher probability to use bank loans for investment growth than those SMEs that do not have colateral

H4: Larger SMEs are having more probability to reach bank loans than smaller SMEs

H5: SMEs with higher turnover have more probability to reach bank loan for investment growth

H6: SME that have regular transaction in international trade have easily gain overdraft for investment growth

H7: SMEs that have experience in international trade are better positioned to get bank loans for investment growth

H8: SMEs that are managed by educated managers have higher probability for geting bank loans for investment growths 


\title{
Florin Peci \\ What determines the allowance of bank loans for investment - an overview of Kosovo SMEs
}

H9: SMEs that obtain audit statements are better positioned to reach bank loans for investment growth

We used linear regression to test our hypothesis. In this model, dependent variable is logarithm of the amount of finances received from banks as bank loans by a given firm in 2012. In the group of independent variables, FIRMEXPORT is a dummy variable that shows whther SMEs using bank loans more frequently are exporting SMEs. The variable BPLAN is also a dummy variable shows that SMEs that have detailed business plans have more chances to obtain investment loans. The variable COLLATERAL shows that SMEs with high collateral are better positioned to obtain bank investment loans. The number of employees has determined the variable LARGFIRMS and it shows that larger SMEs are more prone to benefit bank loans. The variable TURNOVER determined as amount of turnover in Euros and shows that SMEs that have higher turnover can access bank loans. The next variable REGULARTC is a dummy variable shows SMEs that have regular transaction a better positioned to obtain bank loans. Also here is included a variable EXPERIENCE measured through years active in international trade. The dummy variable EDUMANAGER shows that SMEs which are managed by education managers are more capable of getting bank loans. The variable AUDIT as a dummy variable shows that SMEs which are regular in keeping audit statements have more chance to obtain bank loans for investment growth.

\author{
THE MODEL: \\ LnINVESTGROWTH $=\alpha+\beta_{1}$ FIRMEXPORT $+\beta_{2}$ LARGFIRMS $+\beta_{3}$ AUDIT $+\beta_{4}$ COLLATERAL $+\beta_{5}$ \\ TURNOVER $+\beta_{6}$ EXPERIENCE $+\beta_{7}$ BPLAN $+\beta_{8}$ EDUMANAGER $+\beta_{9}$ REGULARTC
}

In this study, we have developed statistical analyses in STATA software. The method for measuring the impact of explanatory variables on depended variable is Ordinary Least Square (OLS). We considered this model as appropriate in order to confirm the variation of variables. Regression linear model is specified well given that R-squared is 0.38 ; showing the variation in independent variables explains $38 \%$ variation in dependent variable. In continuation, the variables FIRMEXPORT, LARGFIRMS, EXPERIENCE and REGULARTC despite that they have positive sign are not significant in statistical aspect. This shows that the firms in Kosovo that export do not differ from other firms in international trade. Regarding the correlation analysis, we can conclude that the problem of correlation in independent variables is not present in our data, given that there are not higher coefficients in our estimation. The dependent variable has a normal distribution and does not represent a statistical problem that requires treatment. In addition, the statistical F-test, shows that rest of the independent variables, jointly are statistically significant, and different from zero.

\section{RESEARCH FINDINGS}

From the results obtained in the model on Appendix 2, it is evident that variable BPLAN have a positive impact on getting bank loan for firm investment. Also, there is a correlation between achieving investments and audit statements that shows that firms which hold audit statements benefit higher investment bank loan (Guffey, 2008). Firms that have collateral have higher possibilities to obtain bank loans and this was also confirmed by Maziku (2012). It is stating that the asymmetric information between the debt-seeking SMEs and the bank is reflected in the incapability of the majority of SMEs to provide consistent financial data and coverage of bank risk through real estate. Other authors have confirmed this also as a key instrument in the decision making regarding the use of banking loans by firms (Zhang, 2008; Madura, 2007).

In addition, there is a positive correlation between investment growth and education of managers. The higher level of professionalism of human capital (education and experience), the better it affects the growth of the firm. Young age and low level of education owners are more prone to use the external sources of financing. Owners of older age and higher education, so-called "wiser" ones are less interested for external sources of financing (Vos et al., 2007). Larger and more experienced SMEs in international trade are not significant in statistical aspect and this shows that the longer presence of those firms in international trade is not determined by their attempt to get loans for investment purposes. 


\section{CONCLUSION}

This paper aimed to explore the factors, which have an impact on investment growth for SMEs that are active in international trade. Internationalization of SMEs is a key factor in their growth and development and a country's economy in general. Therefore, SMEs in international trade are more in need for the bank loans so that they satisfy their increased investment needs in business for expansion and export in other countries. Ability of SMEs to develop proper growth strategy depends heavily on SME's potential to invest in restructuring and innovations. These require capital investments, which necessitates ease access to finance (Mazanai and Fatoki, 2012). According to our findings, bank loan for financing the face export and production is not attractive for banks, which is contrary to other research findings. This is because of the fact that Kosovo banks are not very interested in SMEs which relate debt repayment term longer than other SMEs whose cycle capital is faster and with this the return of bank loan. On the other hand, SMEs that support audit and attest statements regular evidence not only for tax administration purposes but also for banking purposes are the most important factor in the allocation of bank loan for investment purposes in the case of Kosovo, especially SMEs are trading attractive. In the difficult position of getting bank loan for investment purposes are SMEs in the agricultural sector. To be attractive in sharing bank loan to SMEs must possess the sufficient collateral and which can be converted quickly into cash. We finally describe that despite some limitations of the SMEs sector, results obtained can serve as recommendations for SMEs sector in Kosovo and policy making institutions.

\section{LITERATURE:}

- Abor, J. (2008). "Determinants of the Capital Structure of Ghanaian Firms", Small Business Economics, (on line). Available: htpp//www.aercafrica.org//documents/RP176.pdf (2010).

- Acs, Z. and Audretsch, D. (1990). "Innovation and small firms". Cambridge: MIT Press.

- Ahn. S, Denis, D. and Denis, D. (2006). "Leverage and Investment in diversified Firms". Journal of Financial Economics, 79(1)317-337. http://dx.doi.org/10.1016/jfineco.2005.03.002.

- Audretsch, D .B. and Klepper, S. (2000). " Innovation, Evolution of Industry and Economic Growht: Elgar reference Collection", International Library of Critical Writings in Economics, Cheltenham, UK.

- Audretsch, D .B., Elston, J. ( 2006). "Does Firm Size Matter? Evidence on the Impact of Liquidity Constraint on Firm Investment Behavior in Germany ". International Journal of Industrial Organization, 20(1) 1-17.

- Barkham, R. Gudging, G. Hart, M. and Hanvey, E. (1996). "The Determinants of Small Business Growth: An Interregional Study in the UK", 1986-90 Jessica Kingsley: London.

- Baumol, W. (1967). "Business Behavior, Value and Growth", New York: MC Millan.

- Beck, T., Demirguc-Kunt, A., Laeven, L., and Maksimovic, V. ( 2006). "Financial and Legal Constraints to Firm Growth: Does Firm Size Matter", Journal of Finance, 60: 137177.doi.org/10.1016/j.jimonfin.2006.07.005.

- Beck, T.H.L., Demirguc-Kunt, A., and Levine, R. (2007)." Finance, Inequality, and the Poor", Journal of Economic Growth, 12,.27-49.

- Brinckmann, J., Salomo, S., \& Gemuenden, H. G. (2011). "Financial Management Competence of Founding Teams and Growth of New Technology - Based Firms", Entrepreneurship Theory and Practice, vol. 35, no. 2.DOI:10.1111/j.1514.6520.2009.00362.x.

- Caves, R. E. (1998). "Industrial Organization and New Findings on the Turnover and Mobility of Finance", Journal of Economic Literature 36, pp. 1947-1982.

- Curran, J. (1986).: Bolton 15 years on: A Review and Analysis of Small business research in Britain 1977-1986", Small Business Research Trust, London.

- Coleman, S. (2000). "Access to Capital and Terms of Credit: A Comparison of Men - and Women - Owned Small Businesses", Journal of Small Business Management, 38 (3): 37-52. 
- Deakins, D., North, D., Baldock, R., and Whittam , (2008). "SMEs Access to Finance: Is Still Finance Gap?, Institute for Small Business \& Entrepreneurship. Vol. 3 pp 11-19.

- Donaldson, G. (1961) Corporate Debt Capacity: A study of Corporate Debt Policy and the Determination of Corporate Debt Capacity. Harvard Graduate SBA, Boston, USA.

- European Bank for Research and Development (1999)." Transition Report: Ten Years of Transition, London, UK.

- Fatoki, O., \& Asah, F. (2011). "The Impact of Firms characteristics on Access to Debt finance by SMEs in King Williams' Town, South Africa", International Journal of Business and Management, vo. 6, no. 8.http://dx.doi.org/10.5539/ijbm.v6n8p170.

- Ganbold, B., ( 2008). "Improving Access to Finance: International Good Experiences and Lessons for Mongolia", Institute of Development Economics, Tokyo.

- Guffey, M. E. (2008). "Business Communication: Process and Product: 6th Edition,

- Gibrat, R. (1931). "Les Ine'galite's E'conomiques", Librairie du Recueil Sirey, Paris.

- Harris,M., and Raviv,A. (1991). "The Theory of capital Structure", Journal of Finance 46, 297-355

- Harris, R., and Trainor, M.(2005). "Capital Subsidies and their Impact on Total Factor Productivity: Firm Level Evidence from Northern Island ", Journal of Regional Science, vol. 45(1): 49-74http://doi:10.1111/j.0022-4146.2005.00364.x.

- Hartarska, V., \& Gonzales-Vega, C. (2006)." What Affects New Established Firms Expansion. Evidence from Small firms in Russia", Small Business economics, 27, 195-206.DOI 10.1007/s111187-006-0012-0.

- Irwin, D. \& Scott, J.M. (2008). "Barriers to Raising Bank Finance Faced by SMEs", ( working paper no: MS_WPP_MAN_08_03).DOI:10.1108/13551011042816.

- Jarvis, R. Kitching, J. Curran, J. and Lighfoot, G. (2000). The Use of Quantitative and Qualitative Criteria in the measurement of Performance in Small Firms", Journal of Small Business and Enterprize Development, 7(2) 123-134.

- Japelli, T., and Pagano, M. (1994). " Saving, Growth and Liquidity Constraint", Quarterly Journal of economics, 109, 83-109.

- Jensen, M., and Meckling, W. (1976). "Theory of the Firm: Managerial Behavior, Agency Cost and Ownership Structure", Journal of Financial Economics 305360.http://dx.doi.org/10.1016/0304-405x/76/90026-x.

- Johnson. S., and Loveman, G.(1995)." Starting Over in Eastern Europe: Entrepreneurship and Economics Review, 48(3): 261-297.

- Johnson, S. and Storey, D. (1993)." Male and Female Entrepreneurs and Their Businesses: A comparative study", in S. Allen and C. Truman ( eds.), Women Entrepreneurs, London; Routledge.

- Jovanovic, B. (1982). Selection and the Evolution of Industry, Econometrica 50, 649-670.

- Kalleberg, A. \& Leicht, K. (1991)." Gender and Organizational Performance: Determinants of small Business Survival and Success", The Academy of Management Journal, vol. 34, no 1 pp.. 136-161.DOI: $10.2307 / 256305$.

- Krasniqi, B.(2007). "Barriers to Entrepreneurship and SME Growth in transition: The case of Kosova", Journal of Development Entrepreneurship, $12 \quad$ (1):71940.DOI:10.1142/S1084946707000563.

- Krasniqi, B.(2006). Size, Age, and Firm Growth: Econometric Evidence from SME Sector in Kosova", International Journal of management and Entrepreneurship, 2(1):57-68.

- Krasniqi, B. (2010). "Are small firms really constrained? Empirical evidence from Kosova", International Entrepreneurship and Management Journal 2(1):57-68.

- Klapper, L., Sarria-Allende, V. \& Sulla, V. (2002). " SME Financing in Eastern Europe", Washington D. C.: World Bank, Development research group.

- Kon, Y. \& Storey, D.J., (2003). "A Theory of Discouraged Borrowers". Small Business economics, $21,37-49$.

- Lee, S. \& Ratti, R. (2008). "Bank Concentration and Financial Constraint on Firm Level in Europe", Department of Economics, University of Missuri, Columbia.

- Madura, J. (2007). "Introduction to Business", Fourth Edition, South Western :Thomson, USA.

- Marris, R. (1963)." A Model of the "Managerial" Enterprise". Quarterly Journal of economics, 72 (2): $1-33$. 
- Mayers, S.C. \& Majlyf, N.S. (1984). "Corporate Finance and Investment Decision: When Firms Have Information that Investors Do Not Have", Journal of Financial Economics, 13, june, 187222.

- Mazzani , M. and Fatoki, O. (2012). "Access to Finance in SME Sector: A South African Perspective ", Asian Journal of Business Management , 4(1): 58-67.

- Maziku, M. (2012). "Credit Rationing for Small and Medium Scale Enterprises in the Commercial bank Loan market", Dar es Salaam, Tanzania.

- McMillan, J. and Woodruff, C. (2002). The Central Role of Entrepreneurs in Transition Economies. Journal of Economic Perspectives, 16 (3): 153-170.

- Mc Pearson, M. (1996). " Growth of Micro and Small Enterprise in Southern Africa", JDE vol.48 253-277

- Modigliani, F., and Miller, M. (1958). "The Cost of Capital, Corporation Finance and the Theory of Investment ", American Economics Review, 48 (3): 261-297.

- Oliveira, B., and Fortunato, A.(2006). "Firms Growth a Liquidity constrains: A dynamic Analysis", Small Business Economics, 27(1), 139-56. http://dv.doi.org/10.1016/s0167-7187(00)00072-2.

- Ou, C., and Haynes, G.W. (2006). "Acquisition of Additional Equity capital by Small FirmsFindings from the National Survey of Small Firm Finances", National Survey of Small Business Finances, Small Business Economics, 27(2), 157-168. http://dx.doi.org//10.1007/s11187-006-0009-8.

- Pissardies, F., Singer, M. \& Svenjar, J. (2003)." Objectives and constraint of Entrepreneurs: Evidence from Small and Medium Sized Enterprises in Russia and Bulgaria", Journal of comparative economics, vol. 31, no. 3pp 503-31.

- Rand, J. (2007). " Credit Constraints and Determinants of the cost of Capital in Vietnamese Manufacturing". Small Business Economics, 2991), 1-13. http://dx.doi.org/10.1007/s 11187005-1161-2.

- Scott, D.F. (1972). "Evidence on the importance of financial structure" , Journal offinantial mangement, 1(3): 45-60.

- Stigitz, J.E. and Weiss, A.(1981). "Credit Rationing in Markets with Imperfect Information", American Economic Review, 71: 393-410.

- Storey, D. (1994). "The role of Legal Status in Influencing Bank Financing and New Firms Growth", Applied Economics, 26, 129-136.

- Vos, E., \& Yeh, A., \& Carter, S., \& Tagg, S. (2007). "The happy story of Small Business Financing", Journal of banking and 31 Finance, 2648-2672. http://dx.doi.org/10.1016/j.jbankfin.2006.09.011.

- Zhao, H., Wu, W., \& Chen, X. (2006). "What Factors Affects Small and Medium Sized Enterprise's Ability to Borrow from Banks: Evidence from Chengdu City, Capital of South-Western China's Sichuan Province", working paper no.23, Berlin School of Economics.

- Zhang, G. (2008). "The Choice of Formal and informal Finance. Evidence from Chengdu", Journal of China economic Review, 19: 659-678.http://dx.doi.org/10.1016/j.chievo.2008.09.001.

- Watson , J., Newby. R., and Mahuka, A.(2009). "Gender and SME Finance Gap". International Journal of Gender and Entrepreneurship, 1(1):42-56.

- Woldie, A. \&, Leighton, P. \& Adesua, A.(2008). " Factors Influencing Small and Medium Enterprises (SMEs). An Explanatory Study of Owner-Manager and Firm Characteristics", Bank and Bank Systems, vol 3. issue 3, UK.

- World Bank (2005). A better investment climate for everyone: World Development Report 2005. New York: The World Bank and Oxford University Press.

- World Bank (2010). " Kosovo Unlocking Growth Potential: Strategies, Policies, Actions". 
Florin Peci

What determines the allowance of bank loans for investment - an overview of Kosovo SMEs

Appendix 1: Correlation between coefficients at $5 \%$ level of significance

\begin{tabular}{|c|c|c|c|c|c|c|c|c|c|}
\hline & FEXPORT & $\begin{array}{l}\text { LFIRM } \\
\text { S }\end{array}$ & AUD & COLLAT & TURNOV & EXPER & BPLAN & $\begin{array}{l}\text { EDUMA } \\
\mathbf{N}\end{array}$ & REGTC \\
\hline FIRMEXPORT & 1.0000 & & & & & & & & \\
\hline LARGFIRMS & 0.328 & $\begin{array}{l}1.000 \\
0\end{array}$ & & & & & & & \\
\hline AUDIT & 0.0678 & $\begin{array}{l}0.068 \\
4\end{array}$ & 1.0000 & & & & & & \\
\hline COLLATERAL & 0.0888 & $\begin{array}{l}0.089 \\
6\end{array}$ & 0.6603 & 1.0000 & & & & & \\
\hline TURNOVER & 0.0063 & $\begin{array}{l}0.006 \\
4\end{array}$ & 0.1287 & 0.1580 & 1.0000 & & & & \\
\hline EXPERIENCE & 0.0414 & $\begin{array}{l}0.041 \\
7\end{array}$ & 0.3984 & 0.3036 & 0.2015 & 1.0000 & & & \\
\hline BPLAN & 0.0913 & $\begin{array}{l}0.090 \\
4\end{array}$ & 0.2898 & 0.3770 & 0.1592 & 0.2558 & 1.0000 & & \\
\hline EDUMANAGER & 0.0497 & $\begin{array}{l}0.050 \\
1\end{array}$ & 0.1154 & 0.0341 & 0.0886 & 0.0784 & 0.2889 & 1.0000 & \\
\hline REGULARTC & 0.1456 & $\begin{array}{l}0.145 \\
7\end{array}$ & 0.0955 & 0.1101 & 0.0656 & 0.2052 & 0.0936 & 0.6221 & 1.0000 \\
\hline
\end{tabular}

Appendix 2. Determinants of firm investments growth through bank loan financing.

LnINVESTGROWTH | Coef. Std. Err. t P>|t| [95\% Conf. Interval]

FIRMEXPORT |.0000428.0000296 1.45 0.150.0001013.0000157

LARGFIRMS |.000029.0000198 1.470 .144 9.98e-06 .000068

AUDIT |.2188964.0672564 3.25 0.001.0861081.3516846

COLLATERAL |.21416.0498338 4.30 0.000.3125497.1157702

TURNOVER |.1286084.0598119 2.15 0.033.0105183.

EXPERIENCE |.036652.0490946 0.75 0.456.1335824.0602784

BPLAN |.4111606 0616921 6.66 0.000.5329629. 2893583

EDUMANAGER |.3444844.0940774 3.660 .000 158742.5302268

REGULARTC |.104343.0722254 1.44 0.150. 2469418.0382558

_cons |.7006492.2063279 3.400 .001 .29328421 .108014

$N=180$

$R^{2}=0.38$ 